\title{
Rethinking the genre: urban biographies as means of creating critical public spheres
}

\author{
Jaroslav $\operatorname{Ira}^{* \dagger}$ (D) \\ Charles University, Faculty of Arts, Department of General History, Nám. Jana Palacha 1/2, Prague, 116 38, \\ Czech Republic \\ ${ }^{*}$ Corresponding author. Email: jaroslav.ira@ff.cuni.cz
}

\begin{abstract}
In this article, I rethink the genre of urban biographies and argue that it can be given new potency when remodelled to become a means of reinvigorating the critical public. In the first part, I reflect upon some of the recent biographies of cities in the Czech Republic. In the second part, I discuss promising strategies, drawn from a sample of innovative urban biographies. In the final part, I outline the guiding principles of an adapted model for urban biographies. I propose that the cities must be repoliticized and recentred in the biographies, which entails adopting a political concept of the city, a deconstructive approach, utilization of the urban presence and a more urban-sensitive treatment of time.
\end{abstract}

In an ever urbanizing world, many societal challenges have taken on urban dimensions. Some scholars encourage stronger urban citizenship, ${ }^{1}$ seeing the contemporary period as a time in which cities again become actors vis-à-vis weakening nation-states, whereas others declare the urban sphere to be a critical field of the social struggle. ${ }^{2}$ Cities have become a prime locus of identity conflicts and memory clashes, or, as one radical public historian put it, 'crucial barometers of a society's attitude toward preserving the past'. ${ }^{3}$ In this context, it is hardly surprising that the

\footnotetext{
${ }^{\dagger}$ The work was supported by the European Regional Development Fund-Project 'Creativity and Adaptability as Conditions of the Success of Europe in an Interrelated World' (No. CZ.02.1.01/0.0/0.0/ 16_019/0000734). The publication was further supported by the Research Framework of Charles University PROGRES Q09 - History - Key for the Understanding of the Global World. An earlier version of the article was presented as a paper at the 13th International Conference of Urban History 'Reinterpreting Cities', organized by the EAUH in Helsinki, 24-8 Aug. 2016. I wish to express my thanks to Simon Gunn, Veronika Čapská and two anonymous reviewers for their invaluable comments and to Barbara Day and Imogen Davidson White for revision of the English.

${ }^{1}$ R. Bauböck, 'Reinventing urban citizenship', Citizenship Studies, 7 (2003), 139-60.

${ }^{2}$ D. Harvey, Rebel Cities: From the Right to the City to the Urban Revolution (London and New York, 2012).

${ }^{3}$ M. Page, 'Radical public history in the city', Radical History Review, 79 (2001), 115.

(C) Cambridge University Press 2019. This is an Open Access article, distributed under the terms of the Creative Commons Attribution licence (http://creativecommons.org/licenses/by/4.0/), which permits unrestricted re-use, distribution, and reproduction in any medium, provided the original work is properly cited.
} 
call for socially useful or even engaged urban history, the kind that can help citizens to address the contemporary problems of urban society and regain democratic control over their cities, is gaining momentum. For instance, in the closing panel discussion at the 12th Conference of the European Association for Urban History (Lisbon 2014), the urge for a socially relevant urban history resonated strongly.

In this article, I aim to rethink the genre of urban biographies, which are understood here as printed volumes that provide a comprehensive historical depiction of a city. Although the books have received some ingenious consideration in terms of methodology, their contemporary social functions have not been sufficiently addressed. ${ }^{4}$ This sharply contrasts with city museums. Urban biographies and city museums alike are media that provide holistic depictions of the local urban past, certified by historical expertise. Yet it is only the museums that are subject to theoretical reflections as well as concrete attempts to make them into 'agents of social change', or spaces for the exchange of views - in short, media that would resonate with the contemporary experiences of urban citizens. ${ }^{5}$ Urban biographies have eluded such efforts, and at least in east-central Europe, their capacity to play any strong role in the public sphere is meagre. While their prefaces often declare a social purpose, mainly to foster local identity, they are mostly usable as compendia or scholarly handbooks, with their social role limited to raising the prestige of a city. Can we imagine different roles for urban biographies?

In what follows, I argue that urban biographies can contribute to (re)establishing critical urban public spheres and I point to the ways in which this might be achieved. German philosopher Jürgen Habermas famously conceptualized the 'public sphere' as a realm separated from state power, in which private individuals gather as a collective body and discuss issues of public relevance. This category differs from what he called 'representational publicness', through which royal power once showed-off, and which still forms an attribute of public institutions. With the advance of mass society, the public sphere gradually disintegrated as it was increasingly colonized by state power, mass political parties, mass media and large corporations. ${ }^{6}$ A robust public sphere is a vital part of Habermas' concept of discursive democracy, which is based on deliberation as the exchange of points of view that ultimately leads to rationally achieved consensus in a particular soci-

\footnotetext{
${ }^{4}$ See, e.g., D. Reeder, 'The industrial city in Britain: urban biography in a modern style', Urban History, 25 (1998), 368-78; R.J. Morris, 'Urban biography: Scotland, 1700-2000', Urban History, 29 (2002), 276-83; A. Croll, 'Communing with "the laity": exceptionalism, postmodernism and the urban biography', Urban History, 30 (2003), 266-75; I. Germani, 'Rising to the challenge: historians and the "impossible" history of Paris', Canadian Journal of History/Annales canadiennes d'histoire, 45 (2005), 479-90. In the east-central European context, this issue was raised by V. Bácskai, 'Historiografia miest - hlavné trendy a súčasná situácia v Európe', in G. Czoch (ed.), Kapitoly $z$ dejín Bratislavy (Bratislava, 2006). Orig.: Fejezetek Pozsony történetébool magyar és szlovák szemmel (Pozsony, 2005), 15-23; and by R. Traba, 'Ciąglość i historia przerywana: miasto w długim trwaniu', in K.A. Makowski (ed.), O nowy model historycznych badań regionalnych (Poznań, 2007), 75-88.

${ }^{5}$ See, e.g., D. Fleming, 'Making city histories', in G. Kavanagh (ed.), Making Histories in Museums (London, 1996), 131-42; P. van de Laar, 'Challenges for a city museum as intermediary between urban contemporary studies and urban history', unpublished paper, 2018, EAUH conference at Rome.

${ }^{6}$ J. Habermas, The Structural Transformation of the Public Sphere: An Inquiry into a Category of Bourgeois Society (Cambridge, MA, 1991).
} 
ety. ${ }^{7}$ How to restore or improve various realms and procedures for deliberation in modern urban society is clearly beyond the scope of this article, but we can still ask what role urban biographies could play in this. Referring to Habermas' theory, Neil A. Silberman argues that current heritage practice, based on authoritative and one-directional streaming of information to passive audiences, resembles a display of power in the form of 'representational publicness'. What needs to be done is to re-establish the deliberative form of heritage practices, with diverse audiences being genuinely involved and their values and perspectives shared. ${ }^{8}$ Urban biographies may well be added here: these books too often display the power of the new urban elites and of traditional historical expertise; what is worse, they create a mindset that depoliticizes the urban world and demobilizes urban citizens. No wonder, then, that some scholars argue for different media, such as open digital platforms, as successors to the seemingly outdated medium of urban biographies. ${ }^{9}$

While for obvious reasons urban biographies cannot serve as discursive forums in the same way as meetings, on-line platforms or even museums, they can still have many important functions. They can cultivate attitudes that motivate citizens, as well as instruct them, to participate in public discourse. After all, as Simone Chambers argued, Habermasian discourse will hardly take place if citizens are not motivated to act discursively. ${ }^{10}$ According to the familiar A-B-C model, attitudes consist of an affective, a behavioural and a cognitive component. ${ }^{11}$ Applying this model, a socially relevant urban biography can be defined as a book that ideally (a) fosters identities around civic concerns about the city, beyond a sense of local attachment; (b) motivates readers to participate in urban issues; and (c) provides critical and applicable knowledge about the city. We can add (d) as a specifically deliberative point: a socially relevant urban biography emulates deliberation by performing the intra-textual exchange of multiple perspectives and stimulates real debate by suggesting themes for discussion and presenting the city's past and present as a political issue.

The article proceeds in three stages: in the first part, recent biographies of cities in the Czech Republic are reflected upon. In the second part, promising strategies, drawn from a sample of innovative urban biographies, are discussed. In the final part, the contours of an adapted genre of urban biographies that I consider pertinent for the twenty-first century are outlined.

\footnotetext{
${ }^{7}$ See, e.g., J. Habermas, 'Three normative models of democracy', Constellations, 1 (1994), 1-10.

${ }^{8}$ N.A. Silberman, 'Heritage interpretation as public discourse: towards a new paradigm', in M.-T. Albert, R. Bernecker and B. Rudolff (eds.), Understanding Heritage: Perspectives in Heritage Studies (Boston and Berlin, 2013), 21-33.

${ }^{9}$ In the central European context, see, e.g., J. Šedivý, 'Moderná a postmoderná koncepcia urbánnych dejín na príklade Bratislavy’, in R. Červená, T. Dvořák and A. Vyskočil (eds.), Jak psát dějiny velkých měst? (Brno, 2016), 50-72.

${ }^{10}$ S. Chambers, 'Discourse and democratic practices', in S.K. White (ed.), The Cambridge Companion to Habermas (Cambridge, 1995), 247.

${ }^{11}$ See, e.g., D. Albarracín, B.T. Johnson and M.P. Zanna (eds.), The Handbook of Attitudes (Mahwah, NJ, 2005), especially ch. 3.
} 


\section{Experience from the Czech Republic}

Far from being an outmoded genre, the early decades of the twenty-first century saw a flourishing of urban biographies in the Czech Republic and neighbouring countries. While some of them, especially in smaller towns, stemmed from local patriotism, many volumes have been produced as ambitious, multi-authored and up-to-date pieces of scholarship. Many single-volume histories came out as part of the ambitious series History of Czech, Moravian and Silesian Cities by the Lidové Noviny Publishing House. Others were published separately, such as the monumental seven-volume history of Brno. ${ }^{12}$ It was precisely the experience with making the history of the second city in the Czech Republic that brought many Czech, but also some Polish, German, Slovak and Austrian, historians to Brno in 2014 to the conference called 'How to write the history of great cities?' ${ }^{13}$ The underlying assumption of the conference, highlighted by the organizers, but only cursorily addressed by the participants, was that urban biographies had in a way reached their limits and thus demanded a fundamental reflection on their conceptual issues as well as their social relevance. ${ }^{14}$ I take up this challenge here, using an overview of the recent Czech urban biographies as the starting point. To get a picture of the state-of-the-art of the genre, I surveyed a sample of 20 urban biographies ${ }^{15}$ with a specific set of criteria: the declared objectives of the books (particularly the social and political ones); treatment of the present time; overall approach to the synthesis; concept of the city; structuring of time; contextualization in wider frameworks (urban development, larger structures and networks, comparative and transnational perspective); innovations in (urban) history, methodology and theory; form and style; authorship and financial support. The survey revealed the prevalence of established patterns, and a few attempts at innovation.

To start with the objectives, the major aim is to provide a well-based, systematic and reliable knowledge of the city's past. The editor of the Lidové Noviny series

\footnotetext{
${ }^{12}$ Four volumes have been published so far: R. Procházka (ed.), Dějiny Brna, vol. I: Od pravěku k ranému středověku (Brno, 2011); L. Jan (ed.), Dějiny Brna, vol. II: Středověké město (Brno, 2013); L. Fasora and V. Štěpánek (eds.), Dějiny Brna, vol. VI: Předměstské obce (Brno, 2017); J. Kroupa (ed.), Dějiny Brna, vol. VII: Uměleckohistorické památky, historické jádro (Brno, 2015).

${ }^{13}$ Jak psát dějiny velkých měst?, Brno, 19-21 Sep. 2014.

${ }^{14}$ T. Dvořák and A. Vyskočil, 'How to write urban history? Synthesis as an approach to urban history as a theoretical and practical problem in the time of the information revolution. The Great History of Brno project', in Červená, Dvořák and Vyskočil (eds.), Jak psát dějiny, 485-502. (The text serves as the English summary of the book and translation of the opening chapter; all the other chapters are written in Czech, Slovak or German.)

${ }^{15}$ The histories cover major Czech cities, a handful of regional capitals and several district towns. Small towns were disregarded in this article. The books included here are M. Melanová et al., Liberec (Praha, 2017); R. Bláha et al., Hradec Králové (Praha, 2017); V. Smolová et al., Př́ibram (Praha, 2016); T. Adamec et al., Frýdek-Místek (Praha, 2014); P. Holodňák, I. Ebelová and J. Beránek (eds.), Žatec (Praha, 2004); H. Hrachová et al., Rokycany (Praha, 2011); J. Jurok et al., Nový Jičín (Praha, 2011); J. Kilián et al., Teplice (Praha, 2015); V. Ledvinka and J. Pešek, Praha (Praha, 2000); K. Müller et al., Opava (Praha, 2006); R. Pisková et al., Jihlava (Praha, 2009); B. Przybylová et al., Ostrava (Praha, 2013); B. Roedl and A.J. Hluštík (eds.), Louny (Praha, 2005); M. Svoboda et al., Mikulov (Praha, 2013); L. Sýkorová et al., Klatovy (Praha, 2010); M. Tošnerová et al., Beroun (Praha, 2008); J. Wolf et al., Duchcov (Praha, 2013); M. Malivánková Wasková et al., Dějiny města Plzně, vol. I (Plzeň, 2014); K. Waska et al., Dějiny města Plzně, vol. II (Plzeň, 2016); J. Šulc (ed.), Dějiny Olomouce, 2 vols. (Olomouc, 2009).
} 
summarized its major aims in three points: first, to make the larger public familiar with the story of a particular city, which in concrete terms means providing them with the broadest image of the city, of its transformations over time and of the multifaceted life of its inhabitants, and to depict cities as dynamically evolving organisms; second, to present new findings of regional history and revise older ones; third, to point out and stimulate research on the many 'blank spots' (or ignored parts) in city histories. ${ }^{16}$ In several cases, a belief is declared that knowledge of local history will foster identification with the city. But only in a few cases is this idea specified: a sense of local identity is seen as a remedy for the decline of local specificity vis-à-vis global, post-industrial uniformity, ${ }^{17}$ or as a resource that may raise concern for public issues, ${ }^{18}$ or restore identity in places with a discontinuous population, which is the case of cities with a formerly German population, expelled in the aftermath of World War II. ${ }^{19}$ Any stronger social aims or even political engagement seem unacceptable. After all, the explicit task of many volumes is to rectify older, ideologically biased interpretations, or distortions, of local history, i.e. more or less vulgar forms of historical materialism schemes, sometimes combined with the long-established template of ethnic, Czech-German struggle, although this does not make the authors immune from making normative assessments of the Socialist period. What comes most prominently to the fore, however, is the representative purpose of the books that is signalled in forewords and accounts of the books' geneses, and also in material aspects: some of the books are monumental, lavishly illustrated, heavy and expensive.

Urban biographies are invariably linked to public authorities. The production apparatus consists of institutions that are subject to urban and regional governments, such as district or city archives and museums, and of publicly financed universities. While most volumes were at least co-financed by the cities, some were even initiated by them as ambitious urban projects. The making of the multivolume history of Brno, for instance, was subsidized by 15 million Czech Crowns (about $500,000 \mathrm{GBP}$ ) and proudly heralded in media as a major undertaking of the city. ${ }^{20}$ The council of the city of Pilsen followed suit, albeit on a smaller budget. ${ }^{21}$ Even for smaller cities, having an up-to-date biography became a sort of must-have, as reflected in some of the prefaces. Many of the books include the mayor's address or preface. Symbolic needs of the cities, reflecting the logic of inter-urban competition, were often paralleled by interests of history departments at the regional universities, for which the biographies served as a showcase of their expertise as well as a lucrative enterprise. As regards the collectives of authors, they are dominated by historians and archivists, and typically joined by archaeologists, art historians and

\footnotetext{
${ }^{16}$ I. Ebelová, 'Dějiny českých, moravských a slezských měst - ediční řada Nakladatelství Lidové noviny', in Červená, Dvořák and Vyskočil (eds.), Jak psát dějiny, 168-9.

${ }^{17}$ Holodňák, Ebelová and Beránek (eds.), Žatec, 8.

${ }^{18}$ Adamec et al., Frýdek-Místek, 8.

${ }^{19}$ Svoboda et al., Mikulov, 7.

${ }^{20}$ 'Dějiny Brna - vychází první svazek', Brno official city website, www.brno.cz/brno-aktualne/tiskovyservis/tiskove-zpravy/a/dejiny-brna-vychazi-prvni-svazek/, accessed 15 Jun. 2019.

${ }^{21}$ 'Dějiny Plzně zmapuje nová kniha, město na ni dá 1,6 milionu', iDnes.cz, www.idnes.cz/plzen/zpravy/ dejiny-plzne-zmapuje-nova-kniha-mesto-na-ni-da-1-6-milionu-korun.A110202_152042_plzen-zpravy_pp, accessed 15 Jun. 2019.
} 
experts on nature, who are based mostly in regional, sometimes in central, universities, museums and archives. But for a few exceptions, we search in vain for sociologists, ethnologists, geographers, economists or political scientists. Largely missing are also architects or experts on urbanism, although the growing interest in built heritage has brought some heritage protection experts into the collectives. Finally, we will not find any journalists, writers or artists.

The absence of interaction with disciplines that focus on the urban present, as well as the sense of duty to write objective and impartial histories, impacts on the ways that the contemporary period has been approached. In all the researched biographies, the collapse of socialism in 1989 creates a watershed that divides urban time into the closed past and the not-yet evaluable present. Accordingly, some of the volumes avoided covering the post-socialist period altogether, arguing a lack of historical distance, while most of the others resorted to a chronicle-style description of local development, sometimes rich in details, but poor in providing any deeper insight and meaningful orientation. As a result, a rift is created between the past and the present, and the links between contemporary concerns and historical development are missing or ineffective. To be sure, critical remarks on some of the current problems of urban society do appear in some histories, including comments on the decline of local industry, ${ }^{22}$ the rise of consumerism, ${ }^{23}$ the appearance of lowquality architecture ${ }^{24}$ and local controversies about the location of a planned bypass, ${ }^{25}$ or about a new shopping mall in the historical city centre. ${ }^{26}$ Yet these remarks remain scattered in the text, they elude contextualization and fail to serve as gateways for reflection about the problems and contradictions of urban societies.

The biographies do not reflect on the concept of the city and theory of urban development. Markedly missing are also references to wider (European) frameworks of urban history, and so are attempts to set the local history in a comparative or transnational perspective. The cities are largely conceived as containers or stages, and the books provide compartmentalized narratives on the political, social, economic and cultural history of a city, basically tracking manifestations of the general course of (Czech) history as they happened in the city. The systematic analysis of the interactions between local urban spaces and large social processes, the agenda suggested a few decades ago by Charles Tilly, ${ }^{27}$ thus remains unexploited in urban biographies, though it would be instructive in making clear to the local public that 'big history' does not simply affect their city, as if from outside, but that it is co-created there. This approach is reinforced by periodizations that mostly follow phases of Czech political history, although chapters on spatial development and architecture sometimes deviate from this pattern. In some cases, a new agenda slowly steps in that mirrors recent innovations in historical scholarship, such as the symbolic appropriation of space (urban toponymy, monuments), collective memory, the concept of the everyday or a more reflective treatment of inter-ethnic

\footnotetext{
${ }^{22}$ Przybylová et al., Ostrava, 584-7.

${ }^{23}$ Müller et al., Opava, 335.

${ }^{24}$ Pisková et al., Jihlava, 688-90.

${ }^{25}$ Adamec et al., Frýdek-Místek, 462.

${ }^{26}$ Ibid., 450-1.

${ }^{27}$ C. Tilly, 'What good is urban history?', Journal of Urban History, 22 (1996), 702-19.
} 
relations. A remarkable case may be the whole sixth volume of the history of Brno, which deals extensively with the relation between the city and the - gradually incorporated - rural surroundings. In a rare case of interdisciplinary exchange, the volume makes use of ethnological research of the rural culture and the experiences of rural populations. ${ }^{28}$ And yet many other issues and perspectives, such as urban senses, gendered spaces, urban visions and utopias, emotions or environmental perspective, remain out of sight in urban biographies.

While my survey may suggest a sense of discontent, it is not meant as negative evaluation. When assessed on their own terms, many of the biographies, or at least parts of them, can certainly be considered high-quality syntheses, accessible to a broad readership. Many chapters provide well-organized accounts that are accurate, rich in valuable facts and based on a remarkable knowledge of sources and previous research. Moreover, many biographies are indeed foundational in the sense of providing relatively unbiased histories of the twentieth century for the first time. Last but not least, it is worth mentioning that many volumes were co-written by topclass historians with strong academic backgrounds, who are familiar with the theories, recent advances in historiography and larger contexts of the urban, social and cultural history of Europe. In other words, a lack of expertise is not the major problem. What I am concerned about, however, is what might be called 'structural resistance', which blocks the way to more socially relevant biographies. This in-built inflexibility clearly has to do with the genre rules at the micro-level, the production apparatus of the biographies at the meso-level, and the context of east-central Europe at the macro-level.

Starting with the last point, it is perhaps too early to expect engaged histories in a region that still remembers the practice of ideologically biased and officially sanctioned history. The ethos of history being detached from commenting on contemporary problems still lingers. Besides, it is the ways of dealing with the short twentieth century which seems to draw attention, whereas the post-socialist period remains somewhat ignored. On the meso-level, the tight nexus between the cities as public bodies and the biographies co-funded by them is hardly unique for the Czech Republic, but the point is to interrogate the structural barrier this may create for more critical stances to a city's history. Another deadlock is a structural blindness toward the social sciences, the legacy of disciplinary boundary making, which is reflected in the absence of authors who would be willing and capable of addressing the present. Finally, many limits reside deep in the genre rules or in the habit of writing urban biographies. The limited theorization of the city, for instance, seems to originate in the belief that this is simply inappropriate in a historical portrayal of a city, and the more so when it is addressed to the lay public. This is not to suggest that there was no thinking behind the biographies' design. Some introductions revealed dilemmas around the style and structure of the volumes. Yet they seem to have largely remained within the confines of the known world, for instance hesitating between using a more narrative or a more analytical style. And yet, innovative approaches are possible, as the next section will demonstrate.

\footnotetext{
${ }^{28}$ Fasora and Štěpánek (eds.), Dějiny Brna, vol. VI.
} 


\section{Looking for inspiration}

The urban biographies explored above, and almost certainly the majority of urban biographies in Europe, represent what may be called conventional urban biographies. A comprehensive image of the city's past; linearity of the temporal structure; weak social aims; a firm boundary between past and contemporary concerns; limited reflection on the concept of the city; and serious style - those are the most typical features of the genre. Can we imagine different models?

In the following section, I discuss a range of strategies that in some way extend or transgress genre conventions. These are drawn from a sample of innovative urban biographies that serve as representatives of the different strategies. The sample is selective, and there are other examples that in one way or another share these same strategies. Another caveat: the survey leaves aside innovative urban history studies that share some traits of urban biographies, such as concern with a particular city and relatively broad temporal or thematic coverage, but differ in their aim and approach. Analytical and problem-oriented, they do not aspire to comprehensiveness. Moreover, they ultimately aim at understanding wider aspects of society, or urban phenomena, with the city serving more as a sample, whereas in urban biographies the city is the focal point. In east-central Europe alone, a range of innovative urban studies can be mentioned. ${ }^{29}$ From a different part of the continent, David Harvey's well-known analysis of the modernization of Paris ${ }^{30}$ may serve as a model of a highly insightful and socially critical monograph that, indeed, was discussed as a Parisian urban biography. ${ }^{31}$ While it is surely pertinent to inquire how urban biographies could draw inspiration from these urban historical studies, in the following overview I restrict myself only to biographies proper. There is nonetheless an internal variation, as the sample comprises books that range from scholarly styled monographs, to volumes oriented to a wider lay public, to books which are stylized as easy-to-read bestsellers, written in a very captivating style, typically by writers or journalists. The last category clearly foregrounds the literary effect, yet is relevant for our analysis as long as it is based on solid historical knowledge and respect for historical accuracy.

One of the innovative strategies that seems promising particularly in east-central Europe is to exploit the heterogeneous character of the city and write a multiperspective history. Two examples from the region illustrate the case: a history of Wroclaw, written by the well-known British historian Norman Davies, which was published in three languages (English, Polish and German); and a multivolume history of Bratislava, published in the Slovak language. Davies' aims were twofold: to provide an unbiased image, unchained from one-sided, often selective and national(istic) perspectives; and to de-provincialize the history of the city by 'crossing its boundaries', i.e. to point to the many links of the city with other places in the

\footnotetext{
${ }^{29}$ I. Koeltzsch recently discussed three such examples, which are related to Grodno, Lviv and Warsaw in the twentieth century, and which applied the model of city as a palimpsest, city as a space of experience and microhistorical approach respectively. See her 'History takes place: Neuere Forschungen zur Geschichte multietnischer Städte Zentral- und Osteuropas im 20. Jahrhundert', Střed/Centre, 1 (2015), 131-49.

${ }^{30}$ D. Harvey, Paris, Capital of Modernity (London, 2003).

${ }^{31}$ For such a perspective, see Germani, 'Rising to the challenge'.
} 
world and to the multinational context of its history. ${ }^{32}$ The history of Bratislava is likewise designed to provide a 'wide-spectrum depiction of the history of the city' and a 'multicultural and multiethnic perspective' ${ }^{33}$ that would address, from a detached point of view, the appropriations of the city by successive ethnic groups and states (Germans, Hungarians, Czechs and Slovaks), with due respect to their differing narratives. The multiethnic past will give a lesson, as the mayor explains in the preface: 'As if the findings of archaeologists and historians indicated that whoever wanted to settle in the city, ultimately had to replace military encounters with a peaceful coexistence. Life has always found a way to secure the victory of coexistence over hatred - whether neighbourly, social or ethnic. ${ }^{34}$ The multiperspective histories of cities like Wroclaw or Bratislava are clearly desirable and novel. Yet their social function seems to be oriented primarily to historical memory rather than current urban challenges. After all, the biography by Davies ultimately refers to (east-central) European history, which for him seems to be epitomized by Wroclaw, tellingly grasped in the metaphor of 'microcosm'. Lurking in the background is an idea of - and fascination with - a somewhat condensed history of the region, overfilled with nationalisms and totalitarianisms, which makes it very hard to imagine urban histories beyond these frameworks. And yet, in the wake of the current wave of immigration, new nationalism and the heated debates on multiculturalism, multiperspective urban biographies may become a hot topic. What still needs to be done, however, is to link more straightforwardly the narratives of the multiethnic urban past with the politically explosive urban present.

A different strategy of making an urban biography more socially effective is using a suitable theoretical model. This may be exemplified by the history of Ghent written by a collective of urban historians. ${ }^{35}$ The introduction highlights the instructive role of urban history in the contemporary urban world: 'The problems arising from living together in what are often difficult circumstances make it more than worthwhile for us to revisit the experiences of previous generations of city-dwellers. ${ }^{36}$ The book is set in a fairly robust theoretical background, with authors referring to the concepts of socially produced and meaningful space, as theorized within the 'spatial turn', and urban memory that is partly carried by the space. The most promising idea in terms of linking the past and the present, however, is the applied model of the city as palimpsest, which approaches the city as a set of layers, partly still perceptible in the contemporary urban space and functional in urban memory. This model of writing urban biography can be appealing to readers and citizens if only because the journey through history in a way starts from here and now, with the current urban space used 'as a mnemonic device for a historical walk through Ghent as an imaginary museum' and the city's history approached as 'the operation of time and of the past within the urban space'. ${ }^{37}$ That being said, the structure of the book is rather conventional, although the introduction makes clear

\footnotetext{
${ }^{32}$ N. Davies and R. Moorhouse, Microcosm: Portrait of a Central European City (London, 2002).

${ }^{33}$ J. Šedivý and T. Štefanovičová (eds.), Dejiny Bratislavy, vol. I: Brezalauspurc: na križovatke kultúr: od počiatkov do prelomu 12. a 13. storočia (Bratislava, 2012). So far only the first volume has appeared.

${ }^{34}$ M. Ftáčnik, 'Na cestu vedeckému dielu', in Šedivý and Štefaničová (eds.), Dejiny Bratislavy, 13.

${ }^{35} \mathrm{M}$. Boone and G. Deneckere (eds.), Ghent: A City of All Times (Brussels, 2010).

${ }^{36}$ Ibid., 15.

${ }^{37}$ Ibid., 16.
} 
the structuring along a loose timeline and division into periods does not imply 'a classic linear story'. ${ }^{38}$ The text itself is short and purposely selective, aiming at 'synthesis rather than exhaustiveness', and it is the skilful selection of themes, such as infrastructures, urban planning, social conflicts and reused memory of earlier social movements, discussed in a simple but informed way, that makes the Ghent volume an introduction to urban history in general, appealing to audiences beyond its borders.

Different as they are in all other respects, two recent biographies of Amsterdam and Helsinki share another strategy to interest readers in the urban past, based on a particular labelling of the city. The history of Amsterdam by Russell Shorto, an American writer and journalist, employs the label of 'the most liberal city in the world'. ${ }^{39}$ The short and readable book engages with politics by linking Amsterdam's history with the global history of liberalism, the values of which are allegedly in danger. It is precisely the framework of shared values that may effectively link many readers - though clearly not all - with the city, making it 'theirs'. To use a new term in heritage jargon, the Dutch capital comes out as a focal point of the 'heritage community' of liberals or free-thinking people, regardless of their concrete links to the city. ${ }^{40}$ In the case of Helsinki, the authors play with the label of the 'innovative capital'. ${ }^{41}$ In style, the book is much more sober, but it shares with the former a potential to attract the global public: since many of us wish to live in, or govern, innovative cities, we are curious to know the story of the northern miracle, and the authors make the 'wonder aspect' of the relatively young and formerly peripheral city quite explicit. To be sure, the comparative aspect is a departure, rather than an aim, here as in the Amsterdam story: the 'exceptionalism', or 'Sonderweg' of the cities is taken for granted rather than questioned. And of course, the history of Amsterdam is partly a tribute by the author to his 'adopted home', whilst the volume on Helsinki can be read as a self-celebratory portrait of the city. Yet the authors, with Marjatta Hietala being a top-class urban historian, provide much more: the explanation and the clear moral that it is the relentless transfer of knowledge, learning from other cities and openness that has made the Finnish capital so competitive. While still conveying a holistic image of the city, as biographies typically do, the books do not aim to be exhaustive and narrate the histories from their specific angles. In terms of addressees, the two volumes, along with the history of Ghent, target a broader, cosmopolitan and well-educated readership, not least due to the use of the English language, setting up a global public sphere, rather than a local or a national one.

To use urban biographies as platforms for social self-reflection is a strategy adopted by two recent biographies of American cities. The history of Washington by Tom Lewis, with the subtitle 'a history of our national city', draws a portrait that 'aims to render the history and character of the city, the

\footnotetext{
${ }^{38}$ Ibid., 15.

${ }^{39}$ R. Shorto, Amsterdam: A History of the World's Most Liberal City (New York, 2013).

${ }^{40}$ For the spatial openness of the concept of 'Heritage Community', introduced by the Faro Convention on Cultural Heritage, see G. Dolff-Bonekämper, 'The social and spatial frameworks of heritage - what is new in the Faro Convention?', in Heritage and Beyond (Strasbourg, 2009), 71.

${ }^{41}$ M. Bell and M. Hietala, Helsinki: Finland's Innovative Capital, 2nd edn (Helsinki, 2017).
} 
sum of those distinguishing features that give it a unique identity'. ${ }^{42}$ These objectives, however, should not be confused with an aspiration to write an exhaustive history or to create an attractive image of the capital. Rather, the city's history is meant to be a sort of civic-patriotic mirror for the American readership at large. Reading about the capital's history leads to a reflection on the collective identity of Americans: as the city 'embodies so much of the essence of America', it is, for Lewis, 'essential to our understanding of ourselves', and 'has much to tell us about ourselves - who we profess to be, who we really are, and what we might become'. ${ }^{43}$ Lewis makes use of linear chronology, but he deliberately refrains from comprehensiveness. His strategy rests in a selection of stories and details, through which he pursues three major themes in the city's history: the absence of civic government in Washington administration; the importance of race in the city's history; and the symbolic significance of local events for the nation and the world. This aim of using a city's history as a space for reflection on broader issues of (American) public philosophy is even more pronounced by Joanne Reitano in her short history of New York. The biggest American metropolis is also seen as the condensation of many aspirations and problems of American society. Reitano uses a selective strategy as well, with the emphasis on 'unconventional material', which she characterizes as 'various violent and nonviolent conflicts', 'core disputes', 'tensions' or 'struggles' that formed the character of the city. More significantly, the 'perpetual' conflict over issues such as the role of government, the meaning of the community and the impact of economic growth illuminates the perennial debate over change and its effect on the relationship between materialism and humanitarianism, the private and the public interest', reveals 'people's deepest anxieties about the urban order' and 'reminds us of the country's enduring aspirations and remaining agendas'. 44 Although composed as a linear narrative, the book nevertheless blurs the boundaries between the past, the present and the future.

Writing a history from the perspective of present urban life is the strategy adopted in a biography of Los Angeles. ${ }^{45}$ The connection between urban history and a contemporary city creates a constitutive principle, as the editors make clear: "We remained cognizant of the power of history in shaping contemporary life and culture in Los Angeles. While scholars may find history intrinsically fascinating, the enduring significance of historical perspective assuredly springs from its relationship with the present. ${ }^{46}$ The thematic sections of the companion are therefore concluded by essays that provide "contemporary voice" views and visions of specific aspects of life in Los Angeles [and] help to bring the volume's scholarly insights into sharp focus on the human and physical landscapes of early twentyfirst century Los Angeles'. ${ }^{47}$ It is not just the boundaries between the past and the present that are broken; so are those between the text and the audience. To make the book accessible for the lay reader, the editors 'explicitly designed this

\footnotetext{
${ }^{42}$ T. Lewis, Washington: A History of our National City (New York, 2015), xxi.

${ }^{43} I$ Ibid., xxii and xxiv.

${ }^{44} \mathrm{~J}$. Reitano, The Restless City: A Short History of New York from Colonial Times to the Present, 2nd edn (New York and London, 2010), 3-5.

${ }^{45}$ W. Deverell and G. Hise (eds.), A Companion to Los Angeles (Malden and Oxford, 2010).

${ }^{46}$ Ibid., xviii.

${ }^{47}$ Ibid.
} 
book as, in part, a dialogue between historians and non-historians, both within the book's pages and in its outward reach to the public' ${ }^{48}$ Apart from other techniques, such as using photo-essays and dealing with pertinent and controversial issues, a good example of interactivity appears at the beginning of the chapter discussing the trans-local connections of the town in pre-US period. Readers are immediately unsettled by the direct question: 'Is this how you expected the history of Los Angeles to start?' What follows is a short summary of the myth about the unimportance of Los Angeles during the Spanish era and its replacement by rapid development after the coming of Americans. This is concluded by another disturbing question: 'It's a familiar story. But is it true?"49 Rather than merely providing counter-narratives to the dominant version of local history, techniques like this one force readers to confront different versions of local history. To be sure, the structure of the book is unconventional: the companion consists of 25 thematic chapters, clustered in 5 thematic sections. The focus on the present is reflected in the composition of the collective of authors, which includes, besides historians, a couple of political scientists, experts on architecture and urbanism and museum curators, as well as a writer and a photographer.

Disrespect for temporal boundaries, as well as radical experimentation with form, are some of the postmodern strategies applied by the English novelist Peter Ackroyd in his biography of London. The author refutes linearity and singularity of time, arguing in part that the nature of the city itself seems to defy such a concept. $^{50}$ The text therefore moves freely through time, between the past and the present, which, as one recent analyst put it, are 'not separate, distinct periods' in Ackroyd's texts, but rather 'completely interconnected moments of one continuum'. ${ }^{51}$ Yet in spite of Ackroyd's words about labyrinths, the deconstruction of conventional structure into a fragmentary one provides a certain order rather than chaos, combining a loose progression in time with the specific and clustered themes of urban life, which are paradoxically followed with more coherence than in many conventional monographs. The themes, characterized as 'marginal, overlooked, unknown, disreputable histories that often problematize, contradict or disprove official records and versions, ${ }^{52}$ clearly have strong potential to involve readers in a critical approach to the city. 'A bad odour' may be an example: a smell is a quite banal and yet highly contestable urban experience. ${ }^{53}$ The annoying smell of heavy traffic or industrial pollution may connect everyday experience with political issues about the urban regulation of smells and the right to fresh air, and more fundamental questions of the urban world, such as unequal exposure to bad smells that reflect other urban inequalities. Yet what is missing in my view is a more clear-cut trigger that would make a public issue out of Ackroyd's themes. In the

\footnotetext{
${ }^{48}$ Ibid.

${ }^{49}$ L. Pubols, 'Born global: from Pueblo to statehood', in Deverell and Hise (eds.), A Companion to Los Angeles, 20.

${ }^{50}$ P. Ackroyd, London: The Biography (New York, 2000), 2.

${ }^{51}$ P. Chalupský, A Horror and a Beauty: The World of Peter Ackroyd's London Novels (Prague, 2016), 30.

${ }^{52}$ Ibid.

${ }^{53}$ On the inter-relations between urban space, senses and power, see A. Cowan and J. Steward (eds.), The City and the Senses: Urban Culture since 1500 (Aldershot, 2007).
} 
London biography, they ultimately serve to capture a fascinating and unconventional spirit of the metropolis, rather than stir a public debate.

Besides the above strategies, some of the biographies also employed unconventional methods in terms of style and rhetoric. In the case of Amsterdam, for instance, Shorto applies narrative techniques including his own, personal and intimate relation to the city (the book starts with his riding a bicycle around the city); partial stories that reveal the - often very painful - links with other places, such as Anne Frank's story and Auschwitz; movement between various time periods; the use of historical eye-witnesses as narrators; and various similes connected with the recent American political scene; not to mention a very colloquial style. Davies follows a linear chronology in his portrait of Wroclaw, yet the story opens with a captivating and very dramatic account of the city as a bastion of Nazi Germany - actually a cluster of micro-stories of entrapped inhabitants and soldiers - during the final days of World War II. We can see provocative questioning in the companion to Los Angeles, and the dialogical form can be pushed even further. In a short essay, one German historian inventively approached the history of Gdańsk in Poland via a fictive dialogue, with one of the discussants posing 'alternative', or 'contra-factual' questions (e.g. 'What if Solidarity did not start in Gdańsk?') to his counterpart, a stubborn local patriot, addressing in this way the issue of local urban myth-making and collective identities. ${ }^{54}$ Overall, rhetoric is beyond doubt an important attribute, since urban histories can only become tools of the critical public sphere when they manage to engage the readers.

\section{Towards an adapted genre}

We have seen a range of inventive biographies. In what follows, I want to radicalize the lessons we have learned and suggest major guiding principles for writing a socially relevant urban biography. Let us recall what such a biography is ideally capable of: fostering the civic form of urban identity; providing insight into how the city works; encouraging readers for political engagement; imitating the exchange of ideas intra-textually and activating it in the public. With these ideas in mind, two major revisions are essential: the cities in urban biographies must be repoliticized and recentred.

To restore the political dimension of the cities is indeed crucial. Urban biographies can only become stimulators of public debate when their main subject, the city, becomes a matter of public interest. This is what the biographies of Amsterdam and the American cities in particular have implied. To put it another way, the biographies need to reconnect the readers, current politics and the city's history. To recentre the city is very much related to this. The idea may sound absurd, given the obvious centrality of the city in any urban biography. But I have something different in mind: I suggest that the city as such must be the focus and that it is the present and experienced city, the here and now of that city, that should be the vantage point from which the narrative unfolds. For now, the city evades reflection and the perspective typically lies outside of the city. What results then, is a disengaged

\footnotetext{
${ }^{54}$ P.O. Loew, 'Co by było, gdyby Gdańsk...Dialogi o alternatywnej historii miasta', in B. Kerski (ed.), Gdańske tożsamości: eseje o mieście (Gdańsk, 2014), 305-19.
} 
story of the objectified city. What is the remedy to all this? Conceptually, this entails the political notion of the city. Theoretically, this needs the deconstruction of the city as a socially and narratively created entity. Thematically, this calls for rehabilitation of the urban present and the use of current urban problems as the guiding principle. And formally, this requires alteration of some patterns that may assist in depoliticization, such as certain ways of periodization.

The political concept of the city entails more than just seeing the city as a political institution or as a backdrop for big politics; other tasks are implied. First, biographies must rise above 'scalar thought ${ }^{\text {'55 }}$ and reinstate the city as the principal level of social conflicts, thus taking seriously the proposition that Henri Lefebvre famously made, of the city as the mediation between the near order and the far order. $^{56}$ In other words, the city must be approached on equal terms with society, not as its dependent subsystem. The examples of Ghent, Wroclaw and Washington pointed in this direction with their concepts of city as laboratory, city as microcosm and city as mirror of society, respectively. This also means getting over a sense of a mere local relevance, perceiving the city as of secondary importance. The message we got from the biography of Amsterdam says: what happens in Amsterdam concerns all of us. Second, city-biographers must keep away from the misleading language and images of community so typically evoked in prefaces and other paratexts. That means that neither the past city, nor the current one, which is largely coterminous with the implied readership, should be imagined as an apolitical collective. Quite the contrary, the city must be conceptualized as a highly structured society, in which conflicts and tensions are as endemic as feelings of consensus and solidarity. The biography of New York went most resolutely in this direction, but we can go further. Biographers may define the city as an incessant (re)producer of conflicts, and exploit current tensions as the basic structure of the book. They may follow class, gender, race, ethnic or religion-based differences, but they can also embrace more urban-specific collisions, such as those based on various uses of the city: of locals and tourists, drivers and pedestrians, elderly people and youth. This will make the multiperspective model of urban biographies more elastic and appealing to a differentiated public. Finally, biographers should beware of depoliticization, which is often an effect of the narrative: the city emerges as the overarching hero of the story, as a subject to the 'strokes of fate', which obscures a more sociologically accurate concept of the city. ${ }^{57}$ For instance, the Czech biographies reviewed here abound in stories of social conflict, but unlike the American examples where such stories are linked to controversial issues in current society and are thus considered part of 'our collective history', they are neutralized as part of the 'history of the city' in which we just happen to live. The evils of history are extensively narrated, as a lesson for the future, and yet externalized, as if the cities, and the people living there, were merely victims. The dissociation between urban history, which is closed and thus ready for contemplation, and contemporary urban problems is

\footnotetext{
${ }^{55}$ E.F. Isin, 'City.State: critique of scalar thought', Citizenship Studies, 11 (2007), 211-28.

${ }^{56}$ E. Kofman and E. Lebas (eds.), Writing on Cities/Henri Lefebvre (Malden, 1996), 100-1.

${ }^{57}$ The scrupulous analysis of urban history narratives by H. Jansen, The Construction of an Urban Past (Oxford, 2001), may be instructive here, though Jansen uses the term 'urban biography' in a broader sense.
} 
assured, while readers are taught to be mere spectators of urban history, and not its agents.

By deconstruction of the city, I mean the critical knowledge behind and mediated by a biography, on how the cities are socially constructed, how they are woven into larger structures and networks, how agency is constituted on an urban level and how causal relations operate. Indeed, we learn much in biographies about what happened in the city, to the city or with the city, but little about how the city mattered. Given the poor theorization of the city in most biographies, this clearly poses a challenge. There are two issues that must be addressed if urban biographies are to prompt effective political engagement. First, urban biographies should help readers comprehend the socially constructed nature of urban reality. Who spoke on behalf of the city, with what intentions? The processes of imposing on a given city images of urban community and other overarching representations, by politicians, advertisers, urban planners and not least by previous historians, should have a place, perhaps a leading one, in the biography. ${ }^{58}$ Second, urban biographies should raise questions about the conditions and possibilities for meaningful action in the urban setting. Whether from the perspective of an individual, a social group, a movement or the authorities, knowledge about where to conduct various types of action is fundamental. Building on the classical debate of structure vs. agency, ${ }^{59}$ and using insights from the recent explorations of so-called urban agency, ${ }^{60}$ urban biographies may initiate debates on how far, and for whom, it has been possible to influence urban development, whether by individuals in the city, or by the cities in the larger context of structural conditions. Besides providing a compass for action, these biographies can help 'decompose' many of the connected myths; for instance, to provoke questions about how the 'local heroes', who have been monumentalized for their contribution to a city (e.g. former mayors), have been fabricated. Another example: the experience of a local decline can incite critical reflection about uneven development and global dependencies, as well as cultivate critical awareness toward ill-fated policies and prescriptions of urban renewal, which may conceal more fundamental relations of power and economy.

The contemporary situation of the city needs to be employed as a resource to motivate the thematic agenda, rather than be seen as a precarious and often neglected part of the biography. Many options open up here. For instance, if urban biographies are to stimulate debates, why not start with the existing ones? Historians can exploit debates in the daily press, or make use of new sources, such as web forums and social networks, putting the controversies into historical perspective. Alternatively, they can make use of shared routine experiences.

\footnotetext{
${ }^{58}$ For such perspective, see, e.g., M. Gottdiener, 'Culture, ideology, and the sign of the city', in M. Gottdiener and A. Lagopoulos (eds.), The City and the Sign: An Introduction to Urban Semiotics (New York, 1986), 202-18.

${ }^{59}$ For the spectrum of theoretical positions, see A. Callinicos, Making History: Agency, Structure, and Change in Social Theory, 2nd rev. edn (Leiden, 2004).

${ }^{60}$ See, e.g., B. de Munck, 'Disassembling the city: a historical and an epistemological view on the agency of cities', Journal of Urban History (2016), 1-19 (online version), DOI: 10.1177/0096144215621737; I. Van Damme, B. De Munck and A. Miles (eds.), Cities and Creativity from the Renaissance to the Present (New York and London, 2018).
} 
Urban congestion, for instance, which in some way irritates most urban users, may serve as a starting point for historically informed reflection on urban transportation, resilience, ecology and so on. Similarly, elements of urban space can be used, such as buildings that have raised polemics around monumental protection and economic interests, or notorious bad addresses and no-go areas. Inspiration can be drawn from the practice of radical public history tours. As exemplified in the case of criminal activities in urban space, the tours can address structural issues: 'In urban settings, public history tours allow participants to see with their own eyes how the seemingly abstract structure of the law has shaped lived experience and the built environment and continues to structure urban inequality...[and] offer an especially powerful pedagogical tool for reshaping how people think about structural factors that have shaped the world they see. ${ }^{, 61}$ Fragmentary as they may be, these strategies can be powerful stimulators of interest in the city's history, as they create links between present problems, which stir the emotions of readers, and the past. In addition, they align with the way people actually practise a city: as a sequence of situations and experiences, rather than a coherent system or a linear story.

The last point takes us to the form and structure of the narrative. It is particularly the treatment of time that needs consideration. Basing the structure of the narrative on a linear chronology undermines the possibility of writing from the present perspective. This is why some of the reviewed biographies defied this tradition (Ghent, London), while others employed the literary techniques of analepsis and prolepsis (Amsterdam, Wroclaw). Socially relevant histories clearly have to think of creative ways of handling the timeline. In the Czech biographies, the narrative typically starts in pre-historical settlements. Would it not be better to open it with a debate on the political aspects of archaeology and museum displays, with the backdrop of an ongoing excavation that precedes the construction of a contested building in the city centre? The concept of singular time, embedded in many periodizations, can be detrimental as well, as it reduces the complexity of the urban world. The idea of multiple temporalities ${ }^{62}$ that co-exist within any given urban space (the pace of global processes, the rhythm of daily urban routines, the periods of national history, the phases of urban growth etc.) is underemployed in urban biographies. It could help to create a more realistic model, in which dimensions of urban development and experiences are not scaled-down from grand epochs and 'big' political history on top, to 'small' everyday practices at the bottom, but rather considered equally relevant. Related to this is the need for urban-sensitive periodization. In the Czech context at least, the biographies too often rely on major political milestones, which sidelines city histories as derivative of the national history and effectively cuts the urban present from the past. As Ludmilla Jordanova aptly put it, some events are so powerfully embedded in national consciousness, their time-dividing importance being constantly reproduced, that their relegation is hard to imagine. ${ }^{63}$ In east-central Europe at least, it may therefore not be that

\footnotetext{
${ }^{61}$ R. Amato and J.T. Manuel, 'Using radical public history tours to reframe urban crime', Radical History Review, 113 (2002), 212.

${ }^{62}$ For a recent theoretical reflection, see Forum 'Multiple temporalities', History and Theory, 53 (2014).

${ }^{63}$ L. Jordanova, History in Practice (London, 2000), 123-4.
} 
easy to sideline milestones that reflect the political histories of the respective nations, and which still dominate urban biographies, such as the years 1848, 1918, 1938-48 and 1989. The dominance of political temporal frameworks only reinforces the image of the region as defined by political history. This in turn creates a quasi-natural framework of urban history out of the political changes, whilst obscuring other transformations that affected city development and the daily routines of their inhabitants, arguably to a greater extent, such as the advent of new technologies, patterns of production, life-styles and the like - captured by the terms 'post-industrial age', 'postmodernity' or 'globalization'.

\section{Conclusion}

In this article, I argue that the genre of urban biographies should be remodelled to take an active role in the reinvigoration of the critical public sphere. Reflecting on recent biographies in my home country exposed some genre-based constraints, whereas surveying a handful of innovative biographies from Europe and the USA showed that it is possible to break these constraints and invent new models. Drawing on their lessons, I suggest that new biographies have to re-politicize and re-centre the cities in their narratives. So far, the story of the city is the focal point, and an obsession with the narrative ultimately makes it closed and sterile. Instead, urban biographies should centre the current urban experience, to inform and motivate citizens to engage in public discourse. I plead therefore for a more open way of writing, even if that leads to selectiveness and fragmentation, and, undoubtedly, goes against the grain of much of historical writing tradition. The political concept of the city, a deconstructive approach to urban reality, the use of the contemporary urban presence for guiding the thematic agenda, and a more experimental use of time and structure, are all ways to break the genre confines of urban biographies - just like the city museums strive to break their walls - and make urban biographies a powerful tool in restoring critical public spheres.

Cite this article: Ira J (2021). Rethinking the genre: urban biographies as means of creating critical public spheres. Urban History 48, 162-178. https://doi.org/10.1017/S0963926819001123 